Boston University School of Law

Scholarly Commons at Boston University School of Law

Faculty Scholarship

2002

Moral Progress, Mental Retardation, and the Death Penalty

George J. Annas

Follow this and additional works at: https://scholarship.law.bu.edu/faculty_scholarship

Part of the Health Law and Policy Commons 


$$
\text { Legal Issues in Medicine }
$$

\section{Moral Progress, Mental Retardation, and the Death Penalty}

\author{
George J. AnNAS, J.D., M.P.H.
}

\section{$\mathrm{T}$} WO major aspects of the death penalty in the United States directly involve physicians: how the death penalty is carried out and who is subject to execution. As a matter of constitutional law, both are governed by the prohibition against "cruel and unusual" punishment in the Eighth Amendment. The meaning of "cruel and unusual," unlike every other part of the U.S. Constitution, is determined by public opinion as it reflects society's evolving standards of decency. With regard to how the death penalty is carried out, the role of physicians in capital punishment has been controversial for more than two decades. ${ }^{1-3}$ As traditional methods of execution, such as hanging, electrocution, and the gas chamber, have been rejected by the courts as cruel and unusual, lethal injection, with its aura of medical legitimacy, has become the almost universal method of choice in the United States.1 "Killing with kindness" by lethal injection has had a major role in continued public support for the death penalty. ${ }^{1,4}$ Physicians can play many parts in capital punishment, including preparing the prisoner for execution, supervising the execution, and pronouncing the prisoner dead, most of which are considered unethical. ${ }^{1-3}$ A physician invented the guillotine, and physicians regularly supervised executions - from the naval surgeon who made sure that the hanging of Melville's Billy Budd was "scientifically conducted" 5 to the physician who pinned a white circle over Gary Gilmore's heart as a target for the firing squad. ${ }^{6}$

The second major aspect of the death penalty that involves physicians is the determination of who is ineligible for execution. A new decision by the U.S. Supreme Court, Atkins v. Virginia, expands a past prohibition against executing mentally incompetent persons to include a prohibition against the execution of a person with a diagnosis of mental retardation. ${ }^{7,8}$ Since this decision was based on the Court's view that public opinion has evolved to a point at which society views the execution of a mentally retarded person as cruel and unusual punishment, it is critical to understand the political context of the decision, which is best il-

From the Health Law Department, Boston University School of Public Health, Boston. lustrated by the part the death penalty (and its application to retarded persons) has played in presidential politics. Michael Dukakis, who opposed the death penalty, was brutalized in his presidential campaign for being soft on crime. In the next presidential race, Bill Clinton took time off from his New Hampshire primary campaign to return to Arkansas to preside over the execution of Rickey Ray Rector. Rector was a violent criminal, but after murdering a police officer, he shot himself in the head. He survived but had severe brain damage.

Rector did not fit the medical definitions of mental retardation (since his condition did not manifest itself by 18 years of age), but he was widely considered by the public to be retarded. Nonetheless, the courts found him competent to stand trial and, later, competent to be executed, ruling that any clemency would have to come from Governor Clinton., ${ }^{9,10}$ None was forthcoming, even though there is little doubt that Rector did not understand that he was going to be executed, as illustrated by the fact that just before his execution he decided to save the pecan pie from his last meal so that he could eat it before he went to bed that night. ${ }^{11}$ The sympathy of the public, however, was clearly with the families of Rector's victims rather than with Rector himself. After the execution of Rector, the "soft on crime" label that had plagued Dukakis could not be pinned on Clinton. As political consultant $\mathrm{Da}$ vid Garth put it, Clinton "had someone put to death who had only part of a brain. You can't find them any tougher than that." 12

Bill Clinton's decision to permit the execution of a prisoner with severe brain damage was made 10 years ago. Three years before that, the U.S. Supreme Court had decided that it was not cruel and unusual punishment under the Eighth Amendment of the U.S. Constitution to execute a mentally retarded person. This was because mental retardation could be taken into account as mitigating evidence in imposing sentence, and because there was "insufficient evidence" of a "national consensus against execution of the mentally retarded." 13 And in 1999, after the Texas Senate voted to ban the execution of the mentally retarded, Governor George W. Bush voiced his opposition, saying, "That's up to juries to make those decisions. . . . I like the law the way it is right now." 14

In June 2002, in Atkins, the U.S. Supreme Court reversed itself, ruling that the values of Americans have shifted during the past decade and that there now is a national consensus opposing the execution of the mentally retarded. ${ }^{8}$ Directly at issue in this case are global questions of moral progress and human dignity. Indirectly implicated is the related issue of the role of medicine and physicians in the death penalty. The case involved Daryl Renard Atkins and the decision of the Commonwealth of Virginia to execute him. 


\section{THE CRIME}

After a day spent drinking alcohol and smoking marijuana, William Jones and Daryl Renard Atkins abducted Eric Nesbitt outside a convenience store at midnight. They robbed him of the cash he was carrying and drove him in his pickup truck to an automated teller machine, where they forced him to withdraw an additional \$200. They then took him to a deserted area, where, despite his pleas, he was shot eight times, in the thorax, abdomen, arms, and legs, and killed. Each defendant testified that the other had fired the shots that killed Nesbitt, but the jury evidently believed that Atkins had done it. Jones was permitted to plead guilty to first-degree murder in exchange for his testimony against Atkins. This plea made Jones ineligible for the death sentence. ${ }^{8}$

At the penalty phase, the defense relied solely on the testimony of Evan Nelson, a forensic psychologist who had evaluated Atkins before the trial and found him "mildly mentally retarded." His conclusion was based on interviews with Atkins and people who knew Atkins, a review of his school and court records, and the measurement of his IQ as 59 on the Wechsler Adult Intelligence Scale. The jury sentenced Atkins to death, but the Virginia Supreme Court ordered a second sentencing hearing because the judge had used a misleading verdict form. At the second hearing, Nelson testified again. This time, however, the state presented its own forensic psychologist, Stanton Samenow, who testified that Atkins was not mentally retarded but rather was of "average intelligence at least." The jury also heard testimony about the defendant's 16 prior felony convictions for robbery, attempted robbery, abduction, use of a firearm, and maiming. He was again sentenced to death, and the Virginia Supreme Court affirmed the sentence. ${ }^{15}$ Two judges dissented, noting that Samenow's opinion that Atkins possessed average intelligence was "incredulous as a matter of law" and concluding that "the imposition of the sentence of death upon a criminal defendant who has the mental age of a child between the ages of 9 and 12 is excessive." In their words, "It is indefensible to conclude that individuals who are mentally retarded are not to some degree less culpable for their criminal acts. By definition, such individuals have substantial limitations not shared by the general population. A moral and civilized society diminishes itself if its system of justice does not afford recognition and consideration of those limitations in a meaningful way." 15

\section{THE PUNISHMENT}

The U.S. Supreme Court decided to hear the appeal of Daryl Atkins not only "because of the gravity of the concerns expressed by the dissenters" but also "in light of the dramatic shift in the state legislative landscape that has occurred in the past 13 years."
There was only one question before the Court: is the execution of a mentally retarded defendant "cruel and unusual punishment" prohibited by the Eighth Amendment of the U.S. Constitution? The Court had previously ruled that the Eighth Amendment, the text of which reads, "Excessive bail shall not be required, nor excessive fines imposed, nor cruel and unusual punishments inflicted," was based on the "precept of justice that punishment for crime should be graduated and proportioned to the offense."16 Moreover, judgments about whether a punishment is excessive are to be made not on the basis of the standards that prevailed when the Bill of Rights was adopted, but on the basis of those that "currently prevail." Justice Earl Warren put it in a 1958 opinion: "The basic concept underlying the Eighth Amendment is nothing less than the dignity of man. ... The Amendment must draw its meaning from the evolving standards of decency that mark the progress of a maturing society." 17 A determination of existing standards is to be based on "objective factors to the maximum possible extent." 17

As noted above, 13 years ago the Court concluded that executing a mentally retarded person did not violate the Eighth Amendment. ${ }^{13}$ The case involved the brain-damaged, mentally retarded John Paul Penry, who was convicted of brutally raping, beating, and stabbing a woman to death with a pair of scissors. In that case, the Court found that only two states (Georgia and Maryland) had adopted laws banning the execution of a mentally retarded person. Opinion polls showing that large majorities of the public in Texas, Florida, and Georgia opposed executing the mentally retarded, coupled with the fact that 14 states had no death penalty, were considered insufficient evidence to support the conclusion that there was "a national consensus" on the subject. ${ }^{13}$

But, as Justice John Paul Stevens, who wrote for the majority of the Court in the six-to-three opinion in Atkins, noted, "state legislatures across the country began to address the issue," at least partially in response to the Court's 1989 decision. ${ }^{8}$ Since 1990, laws banning the use of the death penalty for the mentally retarded have been passed in Kentucky, Tennessee, New Mexico, Arkansas (which passed its law in 1993, the year after Rector was executed), Colorado, Washington, Indiana, Kansas, New York, Nebraska, South Dakota, Arizona, Connecticut, Florida, Missouri, and North Carolina. The 18 states with such laws do not represent a majority of the 38 states with the death penalty, but the Court decided that "it is not so much the number of these States that is significant, but the consistency of the direction of change, [especially] given the well-known fact that anticrime legislation is far more popular than legislation providing protection for persons guilty of violent crime." ${ }^{8}$ 
The Court, noting further that no state has specifically authorized the execution of the mentally retarded, and that even in the states that still permit it, only five people with an IQ below 70 have actually been executed in the past 13 years, concluded that "the practice . . . has become truly unusual, and it is fair to say that a national consensus has developed against it." $\mathrm{A}$ footnote to this last sentence offers "additional evidence" that the states are reflecting "a much broader social and professional consensus." Such evidence includes positions adopted by professional associations such as the American Psychological Association; Christian, Jewish, Muslim, and Buddhist traditions; the fact that the "world community" overwhelmingly disapproves of executing the mentally retarded; and state and national public opinion polls that demonstrate "a widespread consensus among Americans."

\section{IDENTIFYING THE MENTALLY RETARDED}

Although it left to the individual states the determination of whether a person is mentally retarded, the Court did stress the importance of applying the clinical definition. In this regard, it set forth both the definition of the American Association on Mental Retardation (AAMR) and that of the American Psychiatric Association (APA). The AAMR defines mental retardation as "substantial limitations in present functioning," and elaborates that "it is characterized by significantly subaverage intellectual functioning, existing concurrently with related limitations in two or more of the following applicable adaptive skill areas: communication, self-care, home living, social skills, community use, self-direction, health and safety, functional academics, leisure, and work. Mental retardation manifests before age 18." 8

The definition used by the APA is substantially the same: "The essential feature of mental retardation is significantly subaverage general intellectual functioning (Criterion $\mathrm{A}$ ) that is accompanied by significant limitations in adaptive functioning in at least two of the following skill areas: communication, self-care, home living, social/interpersonal skills, use of community resources, self-direction, functional academic skills, work, leisure, health, and safety (Criterion B). The onset must occur before age 18 years (Criterion C). . . . 'Mild' mental retardation is typically used to describe people with an IQ level of 50-55 to approximately $70 . " 8$

The Court concluded that although such "deficiencies do not warrant an exemption from criminal sanctions . . . they do diminish personal culpability." 8 Specifically, the Court noted that the only two justifications for the death penalty - retribution and deterrence - could not be furthered by executing mentally retarded persons. In regard to retribution, the Court had previously noted that the death penal- ty must be reserved for particularly extreme crimes. In this context, the Court concluded, "If the culpability of the average murderer is insufficient to justify the most extreme sanction available to the State, the lesser culpability of the mentally retarded offender surely does not merit that form of retribution." ${ }^{8}$ As for deterrence, the Court found that the same mental deficiencies that make a person retarded make it "less likely that they can process the information of the possibility of execution as a penalty and, as a result, control their conduct based upon that information."

\section{THE DISSENTING OPINIONS}

Dissenting opinions were written by Chief Justice William Rehnquist and Justice Antonin Scalia; they each joined the other's opinion, and both were joined by Justice Clarence Thomas. The Chief Justice was particularly upset that the Court put any weight at all on "foreign laws, the views of professional and religious organizations, and opinion polls in reaching its conclusion," arguing that such sources were irrelevant. Instead, he insisted that only two sources, "the work product of legislatures and sentencing jury determinations," are "objective indicia of contemporary values firmly supported by our precedents." 8

Justice Scalia opined, "Seldom has an opinion of this Court rested so obviously upon nothing but the personal views of its members." Scalia argued that there is no "national consensus," since only 18 of the 38 states that permit capital punishment (or 47 percent) exempt the mentally retarded, and agreed with the Chief Justice that the other sources cited in support of a consensus were irrelevant. He concluded, moreover, that the definitions of mental retardation adopted by the AAMR and the APA will lead to "turning the process of capital trial into a game," because "the symptoms of this condition can readily be feigned," and "the capital defendant who feigns mental retardation risks nothing at all."

\section{MORAL PROGRESS}

Justice Scalia seems to be correct that the justices are voicing their personal opinions of the rightness or wrongness of executing a mentally retarded killer. We can also be skeptical of the concept of moral progress. As philosopher Jonathan Glover has persuasively argued, "At the start of the twentieth century, reflective Europeans were able to believe in moral progress, and to see human viciousness and barbarism as in retreat. At the end of the century [which has seen the results of technology in the service of the destructive side of human psychology], it is hard to be confident either about the moral law or about moral progress." 18 But we do not have to view moral progress as inevitable to believe that human beings can become ashamed of their brutal behavior and take steps to try 
to prevent it. This is what the majority of the countries in the world have done in abolishing the death penalty itself, and what the U.S. Supreme Court has now done in prohibiting the execution of mentally retarded killers.

Scalia is simply wrong to try to read the "cruel and unusual" injunction in the Eighth Amendment as the citizens of the United States would have read it in 1791. I also think that the majority of the Court is correct to look beyond the shores of the United States to what is going on in the rest of the world. After all, we are all members of the same species, we are all endowed with human dignity, and we all share the same planet and future. We do not always or inevitably progress to be better people, but we should certainly not aspire to limit our national morality to that of an age in which none of us live and in which almost none of our technology existed.

\section{WHITHER CAPITAL PUNISHMENT?}

The Court's opinion has evoked contrasting responses concerning its effect on the broader question of the death penalty itself. One view is that this opinion may be seen as part of an inexorable, if slow, march of moral progress toward the abolition of the death penalty. ${ }^{19}$ In this view, the United States has become, as the Court noted, increasingly out of step with the democracies of the rest of the world. In a post-September 11 world, we not only line up with countries in the "axis of evil" in maintaining our death penalty, we also make it less likely that any European country will extradite suspected terrorists to the United States, because of the possibility that they will face the death penalty.

The contrasting view holds that the public's support for the death penalty only erodes when it is applied in ways that seem unjust and unfair, such as against the mentally retarded or those whose lawyers fall asleep during their trials. If these cases were removed from the domain of the death penalty, its use in the remaining cases might seem fair and just; if so, the death penalty itself would be more likely, rather than less likely, to survive. ${ }^{20}$

Following the logic of Atkins, the next category of killers most likely to be exempted from the death penalty are those who were 16 or 17 years of age at the time they committed the crime (constitutional law prohibits the execution of criminals 15 years of age or younger). ${ }^{21}$ Nonetheless, in October 2002, in a habeas corpus petition in which five votes were needed, only four justices voted to take up this issue. ${ }^{22}$ Shortly thereafter, Attorney General John Ashcroft decided that the accused Washington, D.C.--area snipers who were arrested in October would be tried in Virginia, because it permits the execution of juvenile offenders and one of the accused is 17 years old. ${ }^{23}$

\section{THE ROLE OF PHYSICIANS}

In May 2002, the American Medical Association "strongly reaffirmed" its opposition to the participation of physicians in executions, as outlined in its frequently updated ethical statement on capital punishment. ${ }^{24}$ It is likely that, as a result of Atkins, more convicted killers will want to be labeled mentally retarded, and more physicians and psychologists will be asked to become involved in evaluations. Serving as an agent of the state and using one's medical skills to help make a mentally ill prisoner "fit" for execution is, of course, a perversion of medicine, in the same category as monitoring the health of a person who is being tortured. ${ }^{25}$ But the application of medical criteria to the possible end of removing someone from within the reach of the death penalty on the basis of mental retardation need not be classified as unethical medical work that puts the physician in the service of the state's death machinery. Because the medical criteria used to diagnose mental retardation are so vague, however, it may be difficult for physicians to act in any but a political manner in this context, at least in borderline cases. Terms such as "substantial limitations" and "significantly subaverage," for example, are inherently subjective. IQ tests are notoriously misleading, and there is no blood test or other more objective clinical test to determine whether someone is mentally retarded. ${ }^{26}$ Moreover, physicians could understandably decline to participate in this way, even before trial, arguing that their participation in any phase of a proceeding that could end in the death penalty lends legitimacy to capital punishment and thus makes medicine complicit in executions.

As the Court makes clear in finding the execution of the mentally retarded unconstitutional, the continued ability of the justices to support the constitutionality of the death penalty rests on its approval by public opinion. Public opinion has turned against virtually all forms of execution except lethal injection, because this medicalized form of killing makes capital punishment appear much more benign and certainly less grisly than hanging, electrocution, gassing, or the use of a firing squad. Public opinion, as ascertained by the U.S. Supreme Court, has also turned against the execution of certain categories of persons, now including the mentally retarded. Not only does medicine determine how the state may execute condemned persons, but medicine must now also determine who is eligible to be put to death by the state. Therefore, I think physicians have a special ethical responsibility to participate actively in the ongoing debate over capital punishment.

\section{REFERENCES}

1. LeGraw JM, Grodin MA. Health professionals and lethal injection execution in the United States. Hum Rights Q 2002;24:382-423. 
2. Truog RD, Brennan TA. Participation of physicians in capital punishment. N Engl J Med 1993;329:1346-50.

3. Curran WJ, Casscells W. The ethics of medical participation in capital punishment by intravenous drug injection. N Engl J Med 1980;302:226 30 .

4. Annas GJ. Killing with kindness: why the FDA need not certify drugs used for execution safe and effective. Am J Public Health 1985;75:1096-9. 5. Berthoff W, ed. Great short works of Herman Melville. New York:

Harper \& Row, 1966:419.

6. Mailer N. The executioner's song. Boston: Little, Brown, 1979:985-7.

7. Wainwright v. Florida, 477 U.S. 399 (1986).

8. Atkins v. Virginia, 122 S. Ct. 2242 (2002).

9. Rector v. Lockhart, 727 F. Supp. 1285 (E.D. Ark. 1990).

10. Rector v. Clinton, 398 Ark. 104, 823 S.W.2d 829 (1992)

11. Olgiati C. The White House via death row. Guardian (London)

October 12, 1993:18.

12. Frady M. Death in Arkansas. The New Yorker. February 22, 1993:132.

13. Penry v. Lynaugh, 492 U.S. 302 (1989).

14. Root J. Bush against bill banning death penalty for retarded. Ft. Worth Star-Telegram. April 13, 1999:12.

15. Atkins v. Virginia, 260 Va. 375, 534 S.E.2d 312 (2000).
16. Weems v. United States, 217 U.S. 349 (1910).

17. Trop v. Dulles, 356 U.S. 86 (1958).

18. Glover J. Humanity: a moral history of the twentieth century. New

Haven, Conn.: Yale University Press, 2000.

19. Shapiro B. Rethinking the death penalty. The Nation. July $22 / 29$, 2002:14-9.

20. Kaminer W. The switch. New York Times Magazine. July 7, 2002:7-8.

21. Thompson v. Oklahoma, 487 U.S. 815 (1988).

22. In re Stanford, 202 U.S. LEXIS 8056 (October 21, 2002).

23. Lichtblau E, Blair J. Ashcroft decides Virginia will try sniper cases first: death penalty is at issue. New York Times. November 8, 2002:Al.

24. E-2.06 capital punishment (issued 1980, updated 1994, 1996, 1999 ,

and 2000). Chicago: American Medical Association, 2002. (Accessed November 6, 2002, at http://www.ama-assn.org/ama/pub/category/ 8302.html.)

25. British Medical Association. The medical profession and human rights: handbook for a changing agenda. London: Zed Books, 2001:163-91.

26. Allen DF, Allen VS. Ethical issues in mental retardation: tragic choices/living hope. Nashville: Abingdon, 1979:17-21.

Copyright (C) 2002 Massachusetts Medical Society.

FULL TEXT OF ALL JOURNAL ARTICLES ON THE WORLD WIDE WEB

Access to the complete text of the Journal on the Internet is free to all subscribers. To use this Web site, subscribers should go to the Journal's home page (http://www.nejm.org) and register by entering their names and subscriber numbers as they appear on their mailing labels. After this one-time registration, subscribers can use their passwords to log on for electronic access to the entire Journal from any computer that is connected to the Internet. Features include a library of all issues since January 1993 and abstracts since January 1975, a full-text search capacity, and a personal archive for saving articles and search results of interest. All articles can be printed in a format that is virtually identical to that of the typeset pages. Beginning six months after publication the full text of all original articles and special articles is available free to nonsubscribers who have completed a brief registration.

1818 - N Engl J Med, Vol. 347, No. 22 • November 28, 2002 • www.nejm.org 